\title{
INGER CHRISTENSEN / NOVALIS / PHILOSOPHY OF NATURE
}

The Danish poet and essayist Inger Christensen (1935-2009) has been labelled a modernist, a postmodernist, an experimentalist, and an exponent of systematic poetry. However, all through her works runs her preoccupation with early German romanticism, the philosophical and poetological writings of Novalis in particular. Christensen's complex relationship with Novalis has so far received little scholarly attention. The aim of this tripartite article is to fill this lacuna by shedding light on the various ways in which Christensen engages with Novalis and renegotiates his romantic heritage. Central to Christensen's poetics is a concept derived from Novalis: hemmelighedstilstanden [the state of secrecy]. Reading this concept in conjunction with the contemporary German-Austrian poet Peter Waterhouse's corresponding concept of Geheimnislosigkeit [literally: secretlessness], Silje Ingeborg Harr Svare explores Christensen's renegotiation of Novalis's philosophy of subjectivity and language. Anne Gry Haugland addresses the complex and radical philosophy of nature that resonates throughout Christensen's works. While this philosophy of nature is indebted to German romantic Naturphilosophie, it is also informed by recent developments in the natural sciences: drawing on concepts in contemporary science such as biosemiotics, scalar ratios, and self-organizing systems - Haugland outlines the scientific context for Christensen's philosophy of nature. Finally, Klaus Müller Wille explores the relationship between Christensen's long poem det [It] and Novalis's unfinished philosophical novel Die Lehrlinge zu Sais [The disciples of Sais], showing that det is informed by Novalis's fragment on a structural, a diegetic, a rhetorical, and a conceptual level.

K E Y W O R D S Early German Romanticism, Poetics, Subjectivity, Peter Waterhouse, Philosophy of Nature, Science, Biosemiotics, Semiotics 



\section{SECRET OR SECRETLESSNESS? \\ On Poetological Dialogue and Affinities in Inger Christensen, Peter Waterhouse - and Novalis}

The works of the Danish poet Inger Christensen hold a unique position in the last fifty years of Danish literature. For many years a candidate for the Nobel Prize in literature, Christensen, from her debut in the early 6os to her final volume published in 1991, wrote poems characterized by a striking duality: both avant-garde and classical; simple and enigmatic; literary and reflective, and at the same time immensely popular. In this article I will address one of these ambiguities, namely Christensen's enduring interest in the early romantic philosopher Novalis, an interest which may seem inconsistent with the frequent labeling of her poetry as late modernist, even post-modernist. I will examine Christensen's association with Novalis, most clearly expressed in her early work, det [It] and in her poetics Hemmelighedstilstanden [The state of secrecy], by tracing another kinship: between Inger Christensen and the younger Austrian poet Peter Waterhouse.

In the German-speaking areas, the contemporary Austrian poet Peter Waterhouse is one of those who, through publication and literary events, have helped to highlight the writings of Inger Christensen. ${ }^{1}$ The poetic affinity between Christensen and the younger Waterhouse has also been noticed, and there is little doubt that she has had great influence on his development as a poet. Commenting on a Danish publication of Waterhouse's poetry, the renowned critic Torben Brostrøm writes how Christensen immediately comes to mind, and he states that Christensen reverberates as a 'processed echo' in Waterhouse's poems. ${ }^{2}$

Looking at the key poetological publications by these two authors, it nevertheless is the contrast which is most striking. Inger Christensen published Hemmelighedstilstanden in 2000, after her main lyrical works: det (1969), Brev $i$ april [Letters in April] (1979), alfabet [Alphabet] (1981) and Sommerfugledalen [Butterfly valley] (1991). In the twelve essays collected in Hemmelighedstilstanden, and the 'Digt om døden' [Poem on death] which is also included in this volume, Christensen explores the intertwining of language and the world, concerning herself with language as such, as well as with the language of poetry. The title essay of Hemmelighedstilstanden was written in connection with Christensen's visit to the Viennese 'Schule für Dichtung' in 1992, an institution with which Waterhouse was at that time affiliated. In 1996, four years after Christensen's visit to Vienna, Waterhouse published his own literary poetics, entitled Die Geheimnislosigkeit. Ein Lese- und Spazierbuch [Secretless. A book of reading and walking]. ${ }^{3}$ In this work, 
Waterhouse propounds his idea of a transparency and openness between language and landscape. For Waterhouse, moving in language also means moving in a landscape, and vice versa. This transparency is emphasized by the book's main title, Die Geheimnislosigkeit. It is tempting to ask whether there exists any connection between Christensen's Hemmelighedstilstanden and Waterhouse's Geheimnislosigkeit. Do we find a total opposition in the way the relationship of language to the world is seen in these two books, as the contradiction in their titles might seem to imply? Or is there a deeper connection or a similarity between their poetological positions, making Waterhouse's emphasis on openness and transparency also relevant to the poetry and poetics of Inger Christensen? And, if this is the case, what might this correspondence tell us about the relevance of Novalis to the poetry and poetics of Inger Christensen?

These are the questions that I pursue in this article, using Peter Waterhouse's poetics as lenses on Inger Christensen's poetry as well as on her poetological texts. Firstly, I will sketch how the concept of 'secrecy' found in Inger Christensen's poetics is closely related to Novalis. I then proceed to outline what elements are involved in Waterhouse's poetological understanding of the relationship between language and world as open and secretless. Finally I shall offer a reading of two central poems from Christensen's early systematic composition det. Showing how central elements from Waterhouse's poetics can be recognized and applied in the reading of Christensen's poetry, I will at the end of the essay be able to address the strong association with Novalis which informs the concept of secrecy in Inger Christensen's poetics in Hemmelighedstilstanden.

\section{Secrecy in Novalis and Secretlessness in Waterhouse}

'Der Sitz der Seele ist da, wo sich Innenwelt und Außenwelt berühren. Wo sie sich durchdringen, ist er in jedem Punkte der Durchdringung' [The seat of the soul is located at the meeting-place of the world within and the world without. Where they interpenetrate each other, there it is at every point of interpenetration]. ${ }^{4}$ In this fragment from Novalis's 'Blüthenstaub' we find, in concentrated form, a figure of thought which is perhaps the most consistent in his work - the analogy or correspondence between the interior and the external world. Another passage, this time from the tale of 'Hyazinth und Rosenblütchen', which is included in the unfinished novel Die Lebrlinge zu Saïs [The disciples of Sais], points out that this correspondence is not about the external world being subsumed by the romantic ego: 'Wir verstehn natürlich alles Fremde nur durch Selbstfremdmachung - Selbstveränderung - Selbstbeobachtung' [We naturally understand everything unknown to us only by becoming unknown to ourselves - changing ourselves - considering ourselves].5 The analogy between the interior and the external world recurs in Novalis's aphorism where Inger Christensen has found her central poetological concept, the 'state of secrecy': 'Das Äussere ist ein in einen Geheimniszustand erhobenes Innere' [The outer world is an inner world, raised to a state of secrecy]. ${ }^{6}$ 
The fact that the analogy between the interior and the external world is clear and frequently postulated in Novalis's writings does not make our understanding of it any easier. Pointing to the accentuation of the night and the dream in Novalis's thinking, Otto Friedrich Bollnow suggests that the connection between the interior and the external world should be seen as something deep set and unavailable to our everyday understanding. T The philosopher Nicolai Hartmann offers another explanation. Emphasizing the activist imperative in this central analogy in Novalis, Hartmann ties its characteristics as secret and veiled to the as-yet unrealized, that is to a task given to us. ${ }^{8}$

As Inger Christensen explicates the relationship between language and the world that emerges in the poem by Novalis's term 'state of secrecy', she transfers an analogy concerning the self and the external world to questions of language and world, as when she states that Novalis by this 'søger den altomfattende sammensmeltning af ord og fænomen' [is searching the encompassing fusion of the word and the phenomenon]. ${ }^{9}$ What, then, when it comes to Peter Waterhouse? Is the individual subject in any way involved in the relationship between language and the external world which he explores in his Geheimnislosigkeit?

Hans Eichhorn has pointed out that the transparency between language and the world denoted by Waterhouse's term 'secretlessness' comes into being through a combination of concentration and purposelessness..$^{10}$ When Eichhorn emphasizes how both concentration and purposelessness require simultaneous movement in language and in landscape, he implies someone moving, a pedestrian, so to speak, or in other words a subject. It is worth noting that Waterhouse himself, in the essay 'Gedichte und Teillösungen' [Poems and partial solutions], presents the subjectivity in question as both not-knowing and not-doing. ${ }^{11}$ It is my contention that both the concepts of concentration and purposelessness, and the pedestrian, as well as a certain disability on the part of the subject, are of relevance to Christensen's poetry. Concentrating on two central poems in the systematic poetic work det, I will be able to examine this thesis, before turning my attention back to Hemmelighedstilstanden. Can the parallel reading of Waterhouse's poetics and Christensen's poetry help explain her transfer of Novalis's analogy between the interior and the external world to questions of language and the world, and the ostensible anti-subjectivity of this operation? Can it clarify the secrecy associated in her poetics with the relationship between word and thing, language and the world?

\section{'I see that there is nothing to see' - Necessary Blindness in det}

Inger Christensen's det is organized according to clear principles and with systematic rigor. However, variation and diversity are the most prominent features of this work, and we can detect in it both individual and collective voices. Part of what Christensen's work achieves is to show the interdependence and connection between an individual and a collective aspect of language. In the following 
I shall comment on the two poems which conclude 'LOGOS', the main part of det, namely poems 7 and 8 in the section 'TEKSTEN universaliteter' [TEXT universalities]. The two poems contain a kind of solution to what, during the development of det, has proved to be a struggle to find a foothold in language. This struggle is tied to an individual position, an ' $\mathrm{I}$ '. However, the interconnections between individuality and collectivity in det ensure that the many threads and voices in this complex work are here bound together. ${ }^{12}$

\section{TEKSTEN}

7

Jeg ser at der ikke er noget at se Ser at jeg elsker dig blindt Ser at jeg går ind i en tåge For at finde vej Fordi jeg kan se at i tågen Kan jeg ikke finde vej Ser at disse bevægelser i mig Er trofaste mod mig

\section{[TEXT}

7

I see that there is nothing to see

See that I love you blindly

See that I walk into a fog

To find my way

Because I can see that in the fog

I cannot find my way

I see that these movements within me

Are faithful to me

universaliteter

8

Jeg ser de lette skyer

Jeg ser den lette sol

Jeg ser hvor let de tegner

Et endeløst forløb

Som om de føler tillid

Til mig der står på jorden

Som om de ved at jeg

Er deres ord

universalities

8

I see the weightless clouds

I see the weightless sun

I see how easily they trace

An endless course

As if they trust in me

Here on the earth

As if they know that I

Am their words]

Let me begin with the second of these two poems. The 'Jeg' [I] seeing 'de lette skyer' [the weightless clouds] and 'den lette sol' [the weightless sun] in the first lines suggests a transparency and simultaneity between the individual being and the physical, ambient world. Language, too, partakes in this mirroring and reciprocity. Language and words are presented as correlation and identity: 'Som om de føler tillid / Til mig der står på jorden / Som om de ved at jeg / Er deres ord' [As if they trust in me / Here on the earth / As if they know that I / Am their words]. Here, in the very last lines of the poem, our traditional conception of language as our vehicle for designating the objects of nature is turned upside down. What is being expressed is a notion of the self, the ' $\mathrm{I}$ ', as the language of the clouds and the sun. Rather than the 'I' using language to represent the natural objects, we 
have nature expressing itself through the 'I'. However, the twice repeated 'som om' [as if] (meaning: 'it's after all not so') contradicts the identification and transparency associated with language. Rather than similarity and identity, we have difference and distance.

Recalling Peter Waterhouse's central poetic concept of secretlessness, there is reason to point out how the simple clarity existing between the 'I', language, and the world, in this poem is counterbalanced by something secretive and complex, precisely through the twice repeated 'som om' [as if]. Linking the non-real, the only-apparent, to language and words in this poem might, however, seem to put too much emphasis on language. After all, the term 'words' appears here at the very end of the poem, almost casually, as a loose idea about the self as expression of the natural phenomena. Still, in the larger context of det, the question of the artificiality and non-identity of language is asked continually. The theme of the artificiality of language and the non-identity of language and world is pinned down early on in Christensen's work, and it is turned and flipped towards the very end. The fact that 'ordene er ikke ét / med den verden de beskriver'13 [words are not one / with the world they describe] is pointed out as something highly problematic. The lines 'Ordene bliver hvor de er / mens verden forsvinder' [The words stay where they are / while the world vanishes $]^{14}$ give a compressed expression of what constitutes the point of disclosure and criticism in large parts of det. This general issue concerning language resounds with reiterated 'som om' [as if] and 'ord' [words] in the final poem in 'LOGOS'.

In poem 8, then, we find transparency (which is so central to Peter Waterhouse's poetics) as well as obscurity. As we read the previous poem (poem 7 in 'TEKSTEN universaliteter' quoted above) and consider poem 8 in this light, we are reminded of other salient features of Peter Waterhouse's poetics. Poem 7 opens with a peculiar mixture of blindness and vision: 'Jeg ser at der ikke er noget at se' [I see that there is nothing to see]. The following verses show how the lack of orientation is used as a principle precisely for orientation: 'Ser at jeg går ind i en tåge / For at finde vej / For at jeg kan se at i tågen / Kan jeg ikke finde vej' [See that I walk into a fog / Because I can see that in the fog / I cannot find my way]. In these lines we easily recognize Waterhouse's disabled self - and it is worth taking notice of the fact that this disabled self is not a dissolved self. On the contrary, the 'I's' conscious orientation towards blindness may very well be read as an intentional purposelessness. Given the fact that the world and the natural phenomena stand out with striking clarity in the following poem (poem 8), this clarity can certainly be read as the 'I's' concentrated look at the surrounding nature. Through the blindness of the self, that is the 'I's' disability or fundamental limitation, we find a purposelessness which carries us over from poem 7 to the attentive focus on nature in poem 8.

It is my contention that the central themes in these two final poems - the notknowing self, characterized by a necessary blindness as well as a certain purposelessness and concentration, and the both secretless and secretive relationship between language and the world - recur as the unifying themes in det as a whole. 
But are these themes in any way relevant to Inger Christensen's poetics Hemmelighedstilstanden? That is, should the apparent contrast between the poetological secretlessness of Peter Waterhouse and Christensen's poetics of secrecy rather be seen as a veiled continuity and a dialogue?

\section{Poetological dialogue: \\ Christensen, Waterhouse - and Novalis}

The reiterated 'som om' [as if] in poem 8 reflects on a micro-level the overarching issues of det as a whole - issues concerning the separateness of language, it's non-identity with things. In poem 8 , however, the separateness of language is no longer debilitating, as in prior parts of det, but exists side by side with openness to the natural world. Returning to Hemmelighedstilstanden, we shall see that language's separateness from things in the world not only goes hand in hand with transparency and secretlessness when it comes to the external world, but actually is seen as a prerequisite for this transparency.

Returning to Hemmelighedstilstanden, we should consider Novalis, from whose work Christensen derives her central poetological concept of 'secrecy'. Hemmelighedstilstanden contains numerous references to Novalis, including a long quotation, in Christensen's own translation, from Novalis's text 'Monolog' [Monologue]. 'Monolog' was written in 1798 and deals with the relationship of language to the world. Although short, this text is often considered Novalis's most important philosophical statement. It sets out to define the true nature of language:

Es ist eigentlich um das Sprechen und Schreiben eine närrische Sache; das rechte Gespräch ist ein bloßes Wortspiel. Der lächerliche Irrtum ist nur zu bewundern, daß die Leute meinen - sie sprächen um der Dinge willen. Gerade das Eigenthümliche der Sprache, daß sie sich blos um sich selbst bekümmert, weiß keiner.

[Speaking and writing is a crazy state of affairs really; true conversation is just a game with words. It is amazing, the absurd error people make of imagining they are speaking for the sake of things; no one knows the essential thing about language, that it is concerned only with itself. $]^{15}$

'Monolog' proceeds to proclaim an analogy between language and the world of natural objects: 'Sie machen eine Welt für sich aus - Sie spielen nur mit sich selbst, drücken nichts als ihre wunderbare Natur aus, und eben darum sind sie so ausdrucksvoll - eben darum spiegelt sich in ihnen das seltsame Verhältnißspiel der Dinge' [Their play is self-sufficent, they express nothing but their own marvelous nature, and this is the very reason why they are so expressive, why they are the mirror to the strange play of relationships among things]. ${ }^{16}$ Although Novalis talks about 'mathematischen Formeln' [mathematical formulae], his observation applies to words as well - indeed, such a parallel between mathematical formulae and language is postulated by Novalis: both constitute a self-enclosed world and, 
in so doing, reflect the external world. In Novalis's 'Monolog', then, we encounter the duality of secrecy and secretlessness that was present with such poignancy in the two poems from det discussed above. But what about the ' $\mathrm{I}$ ' in det which 'ser at der ikke er noget at se' [see that there is nothing to see] and thus enters a selflimiting, necessary blindness - in order to make possible another form of vision? Is this self also present in 'Monolog' and in Inger Christensen's poetics?

In 'Monolog' subjectivity certainly seems at first glance to be present only to be mocked by language. However, the inversions which occur in the latter half of 'Monolog' change this view. Here the text's own performative paradox is being addressed. We are informed that language is by its very nature non-instrumental and non-communicative. In the second half of 'Monolog' this paradox is identified as the writer's paradox. How can I speak about the nature of language without at the same time betraying language by using it as a means of communication, the writer asks.

Without going into the details of Novalis's critical confrontation with the idealist philosophical tradition inaugurated by Fichte and his reflection-model of the self, it is nevertheless worth noticing how, towards the end of 'Monolog', the writer-I finds a solution to his own paradox by reconsidering his understanding of himself: 'Wie, wenn ich aber reden müßte? und dieser Sprachtrieb zu sprechen das Kennzeichen der Eingebung der Sprache, der Wirksamkeit der Sprache in mir wäre? und mein Wille nur auch alles wollte, was ich müßte?' [But what if I were compelled to speak? What if this urge to speak were the mark of the inspiration of language, the working of language within me? And my will only wanted to do what I had to do? ${ }^{17}$ These reflections resonate with Novalis's explicit philosophical critique of the concept of the self in German idealism, represented by Fichte. In his Fichte-Studien, written a few years prior to 'Monolog', Novalis develops a critical reading of Fichte's Wissenschaftslehre. He draws attention to language's difference, its non-identity with that which it names, but also the Fichtean understanding of the self as something which constitutes itself. Novalis's objection is directed against Fichte's idea that the self's objectifying grip on itself ('Ich bin ich' [I am I]) should be the basis of its self-knowledge and self-identity. When Novalis, in his Vermischte Bemerkungen [Miscellaneous remarks] (1797), writes that 'Ganz begreifen, werden wir uns nie, aber wir werden und können uns weit mehr, als Begreifen' [we will never understand ourselves entirely, but we are capable of perceptions of ourselves which far surpass understanding], this remark poignantly expresses how his rejection of the reflection-model of the self involves both a constraint and an extension, as can be seen in Manfred Frank's argument that we find a certain romantic scepticism in the thinking of Novalis and other Early German Romantics. ${ }^{18}$ In this line of scepticism, we find a reduction and a limitation of the human capacity for objective knowledge but also, as a function of this reduction, a defense for the individual which is also threatened to be revoked in our objectifying, generalizing thinking.

Returning to the poetry of Inger Christensen, the duality of constraint and extension inherent in Novalis's conception of the individual subject is easily re- 
cognized in the two poems in det discussed above. The 'I' which in poem 7 'ser at der ikke er noget at se' [see that there is nothing to see], and which 'går ind i en tåge / For at finde vej / Fordi jeg kan se at i tågen / Kan jeg ikke finde vej' [walk in the fog / To find my way / Because I can see that in the fog / I cannot find my way], and concedes that 'disse bevægelser i mig / Er trofaste mod mig' [these movements within me / Are faithful to me], can easily be seen as a version of an early-romantic subject. In this and the subsequent poem, blindness and fog open up a different kind of vision. Renouncing purpose and intention, the 'I' becomes able to see what it is surrounded by '[h]ere on earth'. If we recall the initial contrast between the concept of secretlessness in Peter Waterhouse and Inger Christensen's state of secrecy, we may be able to see how the proximity of language to the world in Christensen's poetry and poetics can be both obvious and secretive. The I must be brought beyond its own objectifying abilities in order for it to experience the very basic situation of standing on the earth with the clouds above, illuminated by the sun. 


\section{Notes}

1 Waterhouse edited the antology Ein chemisches Gedicht zu Ehren der Erde. Auswabl obne Anfang obne Ende (Vienna: Residenz Verlag, 1997) and participated with a short essay in Die Weisse Ekstase (Vienna: Folio Verlag, 2008), using drawings by the Austrian artist Johanes Zechner to illustrate excerpts from Inger Christensen's det.

2 Torben Brostrøm, 'Kirsebær smager sødt', Information, Juni 17, 1999, http://www.information. $\mathrm{dk} /$ print $/ 31305$.

3 Peter Waterhouse, Die Geheimnislosigkeit. Ein Lese- und Spazierbuch (Vienna: Residenz Verlag, 1996).

4 Novalis, Schriften, vol. II (Stuttgart: Kohlhammer Verlag, 1960), 419. The English translation is from Classic and Romantic German Aesthetics, ed. J. M. Bernstein (Cambridge: Cambridge, 2003), 205.

5 Novalis, Schriften, vol. III, 429 (my translation).

6 Novalis, Schriften, vol. III, 103 (my translation).

7 Otto Friedrich Bollnow, 'Zum "Weg nach innen” bei Novalis', in Festschrift für Eduard Sprangers 6o. Gerburstag (Berlin: H.Wenke, 1942), 119-40.

8 Nicolai Hartmann, Die Philosophie des deutschen Idealismus, T.1: Fichte, Schelling, und die Romantik (Berlin: Walter de Gruyter, 2012), 191.

9 It should be noted, though, that the exploration of language is of central importance also in Novalis's writings.

10 Hans Eichhorn, 'Der Spaziergänger. Versuch über Peter Waterhouse', Edition Text+Kritik 137, no. 1 (1998): 34 .

11 Peter Waterhouse, “Gedichte und Teillösungen”, in Die Schweizer Korrektur, ed. Urs Engeler, (Basel: Engeler, 1995), 61.

12 For the English translation, see Inger Christensen, it, trans. Susanna Niew (New York: New Direction Books, 2005), 223.

13 Inger Christensen, det, (Copenhagen: Gyldendal, 1969), 53.

14 Ibid.

15 Translated by Joyce P. Crick for Classic and Romantic German Aesthetics, ed. J. M. Bernstein (Cambridge: Cambridge, 2003), 214.

16 Ibid.

17 Ibid.

18 Ibid., 203. See, for instance, Manfred Frank, The Philosophical Foundations of Early German Romanticism (New York: State University of New York Press), 2004. 



\section{NATIVE AND DEEP-ROOTED \\ Positions in Inger Christensen's Philosopby of Nature}

Central to Inger Christensen's philosophy of nature is the idea that the human language - including the language of poetry - may be perceived as part of nature. ${ }^{1}$ We are connected with nature by being part of its multifarious forms, Christensen writes, that is, the language of poetry is indeed a form, a structure, in itself, but also a form which is continuous with the world that it describes. ${ }^{2}$ The poet is indeed creative in her use of language, but the poem's examination of language and the world may just as well be viewed as a reflection of nature in itself: our way of thinking and creating languages (be it mathematical formulas or poems) is an example of nature's forms. When we think about the world through language, it is also the world thinking about itself. ${ }^{3}$

Inger Christensen's writings are rich in references to both science and literature, and by way of references her philosophy of nature points to Novalis, in particular, to his romantic Naturphilosophie. ${ }^{4}$ However, her philosophy of nature is also part of a larger trend unfolding across the canvases of art and science at the time she was writing. In the 1960 s a perspective on nature was developed in a momentum that ran parallel to an increased environmental awareness. A number of shifts and changes in the scientific description of the world took place as new fields of research gained ground. Thus, Christensen's writings represent a time when new scientific discoveries (in the humanities and in the natural sciences) reshaped the perception of nature from viewing the human mind as something radically different from nature towards an understanding of human action and mind as being part of nature. In the natural sciences, chaos and catastrophe theory, models of complex self-organizing systems, and fractal geometry became new interdependent fields of research. This intellectual and scientific movement rekindled an interest in the relationship between the part and the whole, while also identifying universal principles of form that transgressed and challenged the traditional boundaries between the sciences of culture and the sciences of nature. Christensen's writings can be viewed as an expression of these trends. Through poetic language she formulates and explores the osmosis between human and natural processes and unfolds a perspective on nature that includes language itself.

In the essay Hemmelighedstilstanden, Christensen writes: 
Poesien er bare én af menneskets mange erkendelsesformer, og der går det samme skel ned gennem dem alle, hvad enten det drejer sig om filosofi, matematik eller naturvidenskab. Et skel mellem dem, der tror at mennesket med sit sprog står udenfor verden, og dem der oplever, at et menneske med sprog er en del af verden; og at det derfor bliver nødvendigt at forstå, at idet mennesket udtrykker sig, er det også verden der udtrykker sig.

[Poetry is but one of the human forms of insight, and the same dividing line applies to all of them whether it be philosophy, mathematics or natural science. A dividing line between those who believe that man with his language is outside the world and those who think that man with his language is part of the world; and that is why it is necessary to understand that when man expresses himself, the world is also expressing itself.] ${ }^{5}$

Christensen places herself on the latter side of the dividing line. On the other side, we find the conception that nature is radically different from culture and that culture and language are applied to the world from outside, as it were. However, Christensen sees human language and culture as interwoven with and within the world. She uses the terms 'indfødt' [native] and 'indgroet' [deep-rooted] to describe humankind's place in this perspective on nature. ${ }^{6}$ This idea implies transcendence of the absolute dividing line between nature and culture, mind and body, and ultimately between language and the world: a post-dualistic poetics.

I will discuss three different aspects of this poetics - three assumptions in Christensen's philosophy of nature which play a significant role in her works and which have parallels in contemporary science. The three aspects are the idea of a semiotic community between the living, a focus on scalar ratios and division into levels, and finally the conception of the ability of matter to self-organize.

\section{The Nature of Language}

The conception of language as part of nature's idiom is based on a conception of the semiotic precondition of the living:

Jeg er nødt til at finde mening i verden, ikke fordi det er noget, jeg beslutter mig til, måske ikke engang fordi det er noget, jeg ønsker, men fordi jeg som en anden indfødt, på samme måde som et træ er indfødt, ja virkelig som en indgroet del af verden, ikke kan undgå at skabe mening, den mening, som er der i forvejen, og som ustandselig forvalter sin egen forvandling, som det vi forstår ved at overleve.

[I have to find meaning in the world, not because it is something I decide to do or because it is even something I want, but because I, as any other native, in the same way a tree is native, yes, really like a deep-rooted part of the world, cannot avoid creating meaning, that meaning which is already there and which incessantly manages its own transformation as that which we mean by surviving. ${ }^{7}$ 
This passage is taken from a short essay first published in 1991. The title of the essay, 'Den naive læser' [The naive reader], refers to a special writing position described by Christensen: The poet pretends that language and not the poet is writing the poem. Thus, the poem is something that happens, something that emerges with the poet not as creator, but as reader. When Christensen calls her essay the naive reader and not the naive poet, it bespeaks this writing position. The title reflects the poet's relation to the world, a fundamentally semiotic relation: Living is creating meaning. One is only able to survive by interpreting the world and reading the world as signs. This does not apply to human life only, but to life in general. All life (whether it be trees, ants or humans) must read the world and adapt accordingly in order to survive, and human language (whether it be the language of science or art) is simply a refined variation of this basic semiotic condition of life. ${ }^{8}$

From the fields of phenomenology and cognitive semantics, we are familiar with the conception of the anchoring of cognition and language in the bodily experience and in the material 'being in the world'. ${ }^{9}$ But Christensen takes it further and regards this fact as a general condition of life. With the conception of a semiotic community between nature and man, Christensen approaches the research field of biosemiotics. ${ }^{10}$ Christensen does not use the term 'biosemiotics' in her writings, but this branch of scientific investigation is in its basic assumptions very similar to some of Christensen's wordings. Furthermore, biosemiotics is also historically and geographically close to her works (biosemiotics was established in Denmark at a time when Christensen's works were part of the cultural context - so perhaps poetry inspired science?). Biosemiotics shares a number of basic assumptions about levels, complexity and self-organization with the scientific trends already mentioned, and thus it outlines some important points of the new perspective on nature.

Biosemiotics - a scientific field based on the assumption that all living nature is supported by semiosis - is a new scientific field or, rather, a meta-science in the sense that biosemiotics is based on existing scientific knowledge, but provides a new general frame of understanding for the description of living systems. The Danish biochemist Jesper Hoffmeyer's doctoral thesis Biosemiotik [Biosemiotics] from 2005 [2008] is a seminal introduction to the field, but biosemiotics as a concept appears in articles from the 1990s, and the idea of biosemiotics has roots dating back even further.$^{11}$ According to biosemiotics, all living nature is supported by semiosis, and human language is a special variation on the semiotic condition to which everything is subjected. The human language variant differs due to the high volume of what biosemioticians call 'semiotic freedom', which refers to the fact that humans not only read the world through language, but are also capable of creating new fictional worlds in language. ${ }^{12}$ But these fictional worlds are still rooted in the semiotic condition shared by life in general. We are - like nature for that matter - both created and creative: embedded in language, body, biology, and the world. ${ }^{13}$ 


\section{Scale and Level}

Inger Christensen's philosophy of nature is based on the idea that language is embedded in a greater order. This conception is prevalent in her works and she unfolds it especially on the level of form in her poetry, in the individual poems as well as in the overall structure of the works. Christensen is known for her predominant use of systems structuring the works. This applies in particular to her principal works det [It] (1969), alfabet [Alphabet] (1981), and Sommerfugledalen [The butterfly valley] (1991). ${ }^{14}$ Christensen's systems often bear references to processes of nature or to mathematics. ${ }^{15}$ But her use of systems also points to the conceptions of language as an embedded part of nature: by subjecting her poetical form to the system requirements she points out that it is not just the free creativity of the poet which determines the poem. The language of the poem is embedded in the system. By letting the creative process be governed by a system, the poet is thus repeating the embedded character of the language. ${ }^{16}$

Working with scalar ratios, levels and part-whole relationships is a characteristic feature both of Christensen's philosophy of nature and of her poetic strategies. It is important to emphasize that, according to Christensen, the fact that it is possible to find similarities not just between natural and cultural phenomena, but also between different scalar ratios, does not mean that the world becomes easy to grasp. Thus it is of great importance to Christensen that the similarity between part and whole is not an order that overrides the disorderly and makes the world predictable and comprehensible. On the contrary, Christensen points to a constant interaction between chaos and order at all levels, and emphasizes that what recurs at all levels is indeed the relationship between order and disorder, between form and formlessness, between life and death. It is a point made throughout Christensen's writings and it plays a particularly important role in the overall theme of inspiration and creativity in Sommerfugledalen.

\section{Emergence and Inspiration}

A basic question which Inger Christensen asks, as do contemporary trends in science, is whether or not nature itself holds potential for creation: the interpretation of the existence of creative powers in nature, generating new levels by emergent processes, took a decisive turn with the impact of the computer in the 1960 s and 1970s. The immense increases in computing power made it possible to calculate what happens when elements interact in a system over time. By letting the computer calculate long enough it became apparent that emergent properties appear in both biological and physical systems, that is to say not only in animate but also in inanimate nature. Emergence may be interpreted as a term for a creative element in nature in the sense that nature can create something that is not implicit in its earlier stages. In the light of the concept of emergence, order and form are not created either by God or man but from below, from matter itself. ${ }^{17}$ In this context the word self-organization as a term for the phenomenon 
of emergence is quite telling, because it emphasizes that we are dealing with an organization, a creation of form, which is not externally applied to the elements, but rather emerges from within the interacting elements themselves. ${ }^{18}$

The concept of emergence is interesting in relation to Christensen's philosophy of nature because her works continually revolve around the question of creation and inspiration, of what happens in the moment of inspiration when the poem, as Christensen puts it, suddenly writes itself - when the poet achieves the special state of self-abandonment, which Christensen, with a reference to Novalis, calls 'hemmelighedstilstanden' [the state of secrecy]. ${ }^{19}$ It is a phenomenon Christensen describes as equivalent to the scientist's experience when a problem is resolved and the answer becomes obvious. ${ }^{20}$ Christensen's philosophy of nature provides a radical interpretation of this phenomenon. When the poet in 'the state of secrecy' recedes as the creative and controlling subject, a space for the semantic creation process of language becomes available. ${ }^{21}$ The conception of 'the state of secrecy' is therefore a literary analogue to the conception of self-organization and emergence. The systems inserted into the work and governing its creation become a part of this strategy - and the inspiration unlocking the poet's 'state of secrecy' becomes a literary expression of the creative and form-organizing ability in matter. In this sense, both the processes and forms of the mind and art become just as real and natural as the very processes of nature.

Inger Christensen's philosophy of nature is thus based on a conception of nature as complex, level-divided, and self-organizing. As such, her philosophy of nature resembles the philosophy of nature related to significant scientific trends in her time. Combining reflections from numerous sources, from the Bible to chaos theory, on the relationship between language and nature, Christensen develops her philosophy of nature in an ongoing dialogue with literary and scientific traditions. Christensen is thus a writer who pursues her ideas through literature, science and philosophy across time. In so doing her writings reveal connections between romantic Naturphilosophie and recent tendencies in science and the arts. Though the scientific understanding of nature and natural processes has changed dramatically since the romantic period, Christensen's work suggests that romantic philosophers of nature and scientists of the twentieth and twentyfirst century work along the same lines: Both share an interest in interpreting what it means to be human - in a perspective on nature where human beings and their language do not rise above nature, but are considered as part of nature. 


\section{Notes}

1 This article is based on my thesis Naturen $i$ anden - Naturfilosofien $i$ Inger Christensens forfatterskab [Nature in mind - natural philosophy in the writings of Inger Christensen], defended at the University of Copenhagen in 2012. The thesis investigates the complex and radical philosophy of nature which underlies Christensen's writings. In my thesis, as well as in this article, I use the concept 'philosophy of nature' in the widest sense as reflections on the concept of nature not only in the fields of philosophy and science, but also in other disciplines. Thus, poetry can be said to contain a philosophy of nature if it includes considerations of the concept of nature and of man's position in nature. In the writings of Inger Christensen, the philosophy of nature is found more or less in all the poems and novels and in the collections of essays Del af labyrinten [Part of the labyrinth] (Copenhagen: Gyldendal, 1982) and Hemmelighedstilstanden [The state of secrecy] (Copenhagen: Gyldendal, 20oo).

2 Christensen, Hemmelighedstilstanden, 46.

3 Christensen expresses this thought in several essays, e.g. in the essay 'Det er ord alt sammen' [It is all words] in Christensen, Hemmelighedstilstanden, 57.

4 The articles by Silje Ingeborg Harr Svare and Klaus Müller-Wille in this volume unfold this connection.

5 Christensen, Hemmelighedstilstanden, 44 (my translation).

6 See passage quoted below.

7 Christensen, Hemmelighedstilstanden, 12 (my translation).

8 Christensen, Hemmelighedstilstanden, 12-6. The universal semiotic condition that all organisms must read the world in order to survive should not be taken as any specific argument concerning the logical or evolutionary priority of thought versus language in the evolution of our first human ancestors. There is an extensive debate in philosophy, linguistics, and a range of other disciplines about the respective priorities of language and thought. Christensen's philosophy of nature is only relevant for these debates when seen as supporting a general anti-Cartesian stance held by many researchers who claim that both human spoken language and thought are rooted in natural semiotic processes seen in all organisms and not just the human species.

9 The French phenomenologist Maurice Merleau-Ponty in particular plays an important role in Christensen's writings. His phenomenology has also been important to cognitive semantics (as formulated by, e.g., George Lakoff and Mark Johnson in Metaphors We Live By (Chicago: University of Chicago Press, 1980) and for the development of biosemiotics.

10 See Haugland, 'Sprogets natur', Kritik 211 (2014): 65-72 for an introduction to Christensen and biosemiotics. See Haugland, Naturen $i$ ånden (Copenhagen: Institut for Nordiske Studier og Sprogvidenskab, 2012), 201-9, for a discussion of the semiotic approach in Novalis, the Danish linguist Viggo Brøndal, and Jesper Hoffmeyer.

11 Jesper Hoffmeyer, Biosemiotik. En afhandling om livets tegn og tegnenes liv (Copenhagen: Ries Forlag, 2005). English version: Jesper Hoffmeyer, Biosemiotics. An Examination into the Signs of Life and the Life of Signs (Scranton, USA: University of Chicago Press, 2008).

12 Hoffmeyer, Biosemiotik, 222.

13 For an analysis of the duality between being created and creative as a theme in Christensen's novel Azorno (København: Gyldendal, 1967), see Haugland, Naturen i ånden, 116-23. 
14 All works in Inger Christensen: Samlede digte (Copenhagen: Gyldendal, 1998). All three are available in Susanna Nied's English translation: Alphabet (New York: New Directions, 2001); Butterfly Valley (New York: New Directions, 2004); and it (New York: New Directions, 2006).

15 In it, the poems grow as a cell division from the word 'it' with the numbers three and eight as a guiding principle. In Alphabet, two systems meet, namely the alphabet and the Fibonacci sequence, the latter occurring in natural as well as cultural phenomena. In Butterfly Valley, Christensen uses the feedback structure of the crown of sonnets and the focus the crown of sonnets puts on the relation and similarity between part and whole to bring together processes in nature, mind and language.

16 Christensen writes about the numbers in Alphabet and the process of using numbers as a poetical strategy in Christensen, Hemmelighedstilstanden, 125-33.The use of systems as a poetical strategy in the writings of Christensen is also described in Tue Andersen Nexø, 'Vækstprincipper. Systemernes betydning i alfabet', Passage 30 (1998): 77-89; Erik Skyum Nielsen, Modsprogets proces (Copenhagen: Arena, 1982); Erik Skyum Nielsen, Engle i sneen (Copenhagen: Gyldendal, 2000); and Anne Gry Haugland, 'Mønsterdigtning. Betydningsvækst i Inger Christensens lyrik', Kritik 155/156 (2002): 65-76.

17 For a discussion of the history of the concept, see David Blitz, Emergent Evolution (Boston: Kluwer, 1992). For an introduction to the concept, see Steven Johnson, Emergence: The Connected Lives of Ants, Brains, Cities, and Software (New York: Scribner, 2001).

18 The word self-organization is not new either, but it was of central significance in the systems theory of the 1960 and in the complexity research of the 1970 and 1980 s as used by Stuart Kauffman, for example, in his At Home in the Universe (New York/Oxford: Oxford University Press, 1995).

19 Christensen, Hemmelighedstilstanden, 15, 40.

20 Christensen, Hemmelighedstilstanden, 45.

21 Haugland, Naturen $i$ anden, 218-9. 



\title{
DISPERSION, COUNTERSYMBOLS, AND MUTUAL REPRESENTATION
}

\author{
Inger Christensen's det \\ and Novalis's Die Lehrlinge zu Sais
}

The poet Inger Christensen is well known as a preeminent representative of the 'systematic' approach that characterizes Danish poetry of the 196os. ${ }^{1}$ However her work is not only inspired by the contemporary semiotic theories of French and American structuralism. She also alludes to French phenomenology and to the formal vocabulary of the Italian Renaissance. ${ }^{2}$ While the references to these traditions have been explored previously, the close relation between Inger Christensen's writings and the aesthetics of German romanticism has been comparatively neglected.

Fortunately, two recently published $\mathrm{PhD}$ theses illuminate the significance of Christensen's affinity with German romanticism. ${ }^{3}$ In their studies both Anne Gry Haugland and Silje Ingeborg Harr Svare point out the obvious importance of Christensen's extensive use of quotations from Novalis in her long poem det [It] (1969) and in her collection of poetological essays, Hemmelighedstilstanden [The state of secrecy] (2000). Interestingly the two authors arrive at two totally different results. Whereas Haugland uses Christensen's relation to German romanticism to stress the importance of the philosophy of nature in her writings, Harr Svare takes her point of departure in the opposite hypothesis that Christensen's interest in romantic philosophy is based on considerations of language and the subject. Whereas Haugland stresses the clear differences between Christensen's modern philosophy of nature and the holistic thinking of the early nineteenth century, Harr Svare points to the astonishing similarities between Novalis's paradoxical and complex semiotic interests and Christensen's self-referential hermeneutics.

Inspired by these two studies, I would like to develop a third way to look at the relationship between Christensen and the aesthetics of German romanticism. In this context I will concentrate on the relation between Christensen's det and Novalis's novel Die Lehrlinge zu Sais [The disciples at Sais], which is known to centre on 'the relationship between knowledge of nature and self-knowledge'. As mentioned above det contains several quotations from Novalis. Thus each of the eight poems in the section 'TEKSTEN konnexiteter' has an epigraph by Novalis. Despite the fact that the first of these epigraphs derives from Die Lebrlinge $z u$ Sais, neither Haugland nor Harr Svare pay much attention to this particular text. My intention is to remedy this omission. I hope to show that Novalis develops a 
poetical philosophy of nature which Christensen perpetuates in the framework of det. I shall begin with a longer presentation of Die Lebrlinge zu Sais and then demonstrate how Christensen uses Novalis to develop her own epistemological writing methods.

\section{Novalis' Die Lehrlinge zu Sais \\ as an Epistemological Treatise}

Novalis wrote Die Lebrlinge zu Sais in 1798 during his stay at the mountain academy Freiberg, where he devoted himself to widespread studies in science and philosophy. Friedrich Schlegel and Ludwig Tieck published the text - which remained a rather short fragment - in 1802 in the first edition of Novalis's writings. The novel has no proper plot but consists of dramatic monologues and dialogues in a lyrical and rhapsodic style. The first part of the novel 'Der Lehrling', told by an autodiegetic narrator, refers very abstractly to a community of disciples who are instructed by a teacher [Lehrer]. In the second part of the book, 'Die Natur', a group of travellers joins this community. In this part of the novel, it becomes even more difficult to relate the different passages of the text to specific voices or characters.

Earlier scholarship on the text centred on the religious and philosophical impact of these scraps of conversation. Later interpreters have clarified the relation between this impact and the complex artistic structures of the text. ${ }^{5}$ One could show that the two parts, 'Der Lehrling' and 'Die Natur', follow a triadic structured scheme. Because this scheme is characterized by an overarching 'Kompositionsfigur der gegeneinanderlaufenden Tendenzen' [composition figure of opposed tendencies], ${ }^{6}$ it does not constitute a closed totality, but invites the readers to incessant interpretations.

In the context of this short article it is impossible to give a full interpretation of Novalis's hermetic text. Instead I want to concentrate on the semiotic and epistemological models that are discussed in the doctrinal conversations of Die Lebrlinge and which Christensen refers to in her quotations from the text. The passage cited in det comes from the second part of Novalis's book and voices the opinion of 'Mehrere' [several]. That means that the personal pronoun 'wir' refers to an anonymous plural voice:

Wir brauchen nicht erst lange nachzuforschen, eine leichte Vergleichung, nur wenige Züge im Sande sind genug um uns zu verständigen. So ist uns alles eine große Schrift ... [Inger Christensen's omission]

[We do not need to investigate at length; a slight resemblance, a few indications in the sand are enough to inform us. Everything becomes a great Script ...] [Inger Christensen's omission $]^{7}$ 
Christensen skips the final part of the sentence where the 'several' proclaim their almost unlimited cognitive capacity: 'So ist uns alles eine große Schrift, wozu wir den Schlüssel haben, und nichts kommt uns unerwartet, weil wir voraus den Gang des großen Uhrwerks wissen' [Everything becomes a great script to which we have the key; nothing is unexpected because we anticipate the evolution of the great time machine]. ${ }^{8}$ With her omission Christensen stresses the dialogical gesture of Novalis's text which - considered as a whole - abstains from formulating a closed doctrine and instead invites readers to think for themselves. Furthermore, the shortening of the quotation allows her to allude to the famous opening of Novalis's text, where different natural phenomena are described as parts of a wondrous system of written signs which cannot be fixed in unalterable forms and which cannot be decoded with the help of one single key:

Mannigfache Wege gehen die Menschen. Wer sie verfolgt und vergleicht, wird wunderliche Figuren entstehen sehn; Figuren, die zu jener großen Chiffernschrift zu gehören scheinen, die man überall, auf Flügeln, Eierschalen, in Wolken, im Schnee, in Kristallen und in Steinbildungen, auf gefrierenden Wassern, im Innern und Äußern der Gebirge, der Pflanzen, der Tiere, der Menschen, in den Lichtern des Himmels, auf berührten und gestrichenen Scheiben von Pech und Glas, in den Feilspänen um den Magnet her, und sonderbaren Konjunkturen des Zufalls, erblickt. In ihnen ahndet man den Schlüssel dieser Wunderschrift, die Sprachlehre derselben, allein die Ahndung will sich selbst in keine feste Formen fügen, und scheint kein höherer Schlüssel werden zu wollen.

[Men travel by many different paths. Whoever tracks and compares their ways will see wonderful figures arising; figures that seem to belong to the great Manuscript of Design which we descry everywhere, on wings of birds, on the shell of eggs, in clouds, in snow, in crystals, in rock formations, in frozen water, within and upon mountains, in plants, in beasts, in men, in the light of day, in slabs of pitch and glass when they are jarred or struck, in filings around a magnet, and in the singular Coincidences of Chance. In these things we seem to catch an idea of the key, the grammar to this Manuscript, but this idea will not fix itself into any abiding conception, and seems as if it were unwilling to become in its turn the key to higher things. ${ }^{9}$

In one of her later essays, 'Tilfældighedens ordnende virkning' [The regulating effect of chance], Christensen does not simply quote this long passage; rather, the entire argument of the essay can be described as a long unfolding of this particular passage. ${ }^{10}$ Christensen uses Novalis's text to illuminate her central idea that the relation between nature and language should not be described as an opposition, but rather as a form of structural analogy. Similarly, she is interested in the relation, thematised in Die Lebrlinge zu Sais, between the nature of language (or the nature of the mind) and the language of nature (or the spirit of nature). It is not just natural phenomena, such as crystals, mountains, plans or magnetic tracks, which are described as interpretable sign systems. The different methods, too - literally the 'manifold ways'- which the scientists use to discover these sys- 
tems, are seen as signs to be interpreted. In this respect, the quotation does more than just express the old topos of the hidden book of nature. ${ }^{11}$ This topos is combined with the astonishing concept that there are several ways or methods for interpreting these sign systems: 'Men travel by many different paths'. This means that the language of nature is not described as a given semiotic system which can be represented in language in any simple way. On the contrary, nature's semiotic system and its corresponding relations to other semiotic systems can only be analysed when the scientist produces them experimentally. ${ }^{12}$ In this respect, science is described as a constant dialogue, i.e. a constant interaction with nature where the observer and the observed perpetually influence each other. Die Lehrlinge provides a detailed description of the corresponding semiotic experiments in which every new production of semiotic relations goes hand-in-hand with insight into more complex correspondences and analogies which, in turn, change the nature of perception:

$\operatorname{Er}$ [der Lehrer] sammelte sich Steine, Blumen, Käfer aller Art, und legte sie auf mannigfache Weise sich in Reihen ... Auf sein Gemüt und seine Gedanken lauschte er sorgsam. Er wußte nicht, wohin ihn seine Sehnsucht trieb. Wie er größer ward, strich er umher, besah sich andre Länder, andre Meere, neue Lüfte, fremde Sterne, unbekannte Pflanzen, Tiere, Menschen, stieg in Höhlen, sah wie in Bänken und in bunten Schichten der Erde Bau vollführt war, und drückte Ton in sonderbare Felsenbilder. Nun fand er überall Bekanntes wieder, nur wunderlich gemischt, gepaart, und also ordneten sich selbst in ihm oft seltsame Dinge. Er merkte bald auf die Verbindungen in allem, auf Begegnungen, Zusammentreffungen. Nun sah er bald nichts mehr allein.

[He collected stones, flowers and every sort of insect, and set them out in many-fashioned lines. ... He listened heedfully to his own heart and to his thoughts. He knew not whither his longing was driving him. When he was older he wandered, beholding other countries, other seas, new skies, strange stars, unknown plants, animals and men; he descended into caves and marked how in courses and coloured strata the Edifice of the Earth had been built up. He manipulated clay into wonderful rock forms. At this time he found everywhere objects already known to him but marvellously mingled and mated, and strange vicissitudes often arose within him. Soon he became aware of the inter-relation of all things, of conjunctions, of coincidences. Ere long he saw nothing singly. $]^{13}$

The scientific activity starts with the attempt to avoid given modes or schemes of perception which, for example, dissect nature by established taxonomies. Denouncing the 'krankhafte Anlage der späteren Menschen' [the morbid disposition of modern men] that is defined by insane 'Theilungen, Zergliederungen' [divisions, dismemberments] and 'Zerspaltungen' [splittings], ${ }^{14}$ the teacher's production of a new series of objects leads to the recognition of astonishing equivalences. Trying to avoid differentiating between the diverse natural spheres, the teacher uses a method which could be described as a conscious form of 'disper- 
sion'. The dispersed perception leads to the simultaneous observation of objects normally separate from each other.

On first sight, the teacher seems to be interested in an experimental reinvention of a classical, analogical way of thinking which leads to an more genuine 'order of things'. ${ }^{15}$ However, as already noted, the tentatively established equivalences are of less importance than the cognitive effects of the teacher's practise, which, most of all, should change his mode of perception. The observation of similarities and correspondences joins together the observer's senses which have been artificially separated by education: 'In große bunte Bilder drängten sich die Wahrnehmungen seiner Sinne: er hörte, sah, tastete und dachte zugleich' [The perceptions of his senses thronged together in great variegated Pictures; he heard, saw, felt and thought simultaneously]. ${ }^{16}$

Time and again, the disciples examine the aim of these experiments, which should result in a specific form of perception where the scientist influences nature whilst he is being physically and mentally influenced by the forces of nature:

Den Inbegriff dessen, was uns rührt, nennt man die Natur, und also steht die Natur in einer unmittelbaren Beziehung auf die Gliedmaßen unsers Körpers, die wir Sinne nennen. Unbekannte und geheimnißvolle Beziehungen unsers Körpers lassen unbekannte und geheimnißvolle Verhältnisse der Natur vermuthen, ...

[The substance of these impressions which affect us we call Nature, and thus Nature stands in an immediate relationship to those functions of our bodies which we call senses. Unknown and mysterious relations of our body allow us to surmise unknown and mysterious correlations with Nature, ... $]^{17}$

In the light of these complex theoretical reflections on the sensuality of cognition, it is perhaps not surprising that the semiotic and perceptual experiments of the teacher are also described as a poetic activity. The disciples use metaphors of musical forces and affects to characterise the interplay between the manipulating and the manipulated forms of perception. In their eyes, the scientist literally plays on the instrument of nature. He tunes nature as an instrument ('das Instrument stimmen') and he is influenced by the moods of nature ('durch das Instrument gestimmt werden'): 'Der eigentliche Chiffrirer wird ... auf der Natur, wie auf einem großen Instrument phantasieren können, ...' [The interpreter proper will ... improve on Nature as on some great instrument, ... $].^{18}$ This claim also shows the way in which the disciples fuse the musical metaphor with the semiotic activity of ciphering and deciphering. In other words, they describe how the teacher uses semiotic or rhetorical transfers to change his fundamental mode of reading nature. Furthermore, this dynamic process of continuous ciphering and deciphering has as its final aim 'einem innig lebendigen Zustande zwischen zwey Welten' [a condition of relationship between two worlds] where subject and object, 'empfinden und denken' [feeling and thinking], 'Innenwelt' [the interior] 
and 'Aussenwelt' [the external world], nearly coalesce. ${ }^{19}$ The experiments and their rhetorical devices are described more precisely in the beginning of the novel:

Er [der Lehrer] freute sich, Fremdlinge zusammenzubringen. Bald waren ihm die Sterne Menschen, bald die Menschen Sterne, die Steine Tiere, die Wolken Pflanzen, er spielte mit den Kräften und Erscheinungen, ...

[He [the teacher] took pleasure in bringing strangers together. Sometimes the stars became men to him, men as stars; stones were as animals, clouds as plants; he sported with forces and phenomena; ... $]^{20}$

The teacher uses the rhetorical figure chiasmus (Menschen-Sterne - Sterne-Menschen) to establish a new mode of thinking which allows him to modify the conceptual metaphors of his experience. He does not only attempt to comprehend stars by men. Rather, he uses the redoubled metaphor (stars as man, man as stars) to analyse the possibilities and the limits of this analogy. The importance of this specific chiastic way of thinking is also reflected in Novalis's Das allgemeine Brouillon [Notes for a romantic encyclopaedia] where he outlines a 'theory of the mutual representation of the universe' which rests on the following operation: 'Every symbol can be symbolized again by that which it symbolizes - countersymbols'. ${ }^{21}$ Especially the notion of 'countersymbols' - where the two parts of the metaphor ('stars' as tenor, 'men' as vehicle) are inverted ('men' as tenor, 'stars' as vehicle) - is connected to the use of chiasmus.

However, it must be emphasized that the epistemological argument summarized above does not remain unchallenged in Novalis's novel. Rather, the reader is confronted with other voices that explicitly ridicule the teacher's poetic form of natural science:

'Die andern reden irre', sagt ein ernster Mann zu diesen. 'Erkennen sie in der Natur nicht den treuen Abdruck ihrer selbst? Sie selbst verzehren sich in wilder Gedankenlosigkeit. Sie wissen nicht, daß ihre Natur ein Gedankenspiel, eine wüste Phantasie ihres Traumes ist.'

['The others rave', said a serious man to these last. 'Do they not recognise in Nature a true image of themselves. They consume themselves in a savage nescience. They do not know that their Nature is a conjuration of their thought, a barren phantasy of their dream'. $]^{22}$

As we will see in the next section it is precisely this conflicting combination of a highly metaphorical way of thinking and a critique of the metaphor, which Christensen will deepen and sharpen in the framework of det. 


\section{The conception of a 'Wunderschrift' in Inger Christensen's det}

At first sight, it may seem inappropriate to compare a fragmentary novel of the early nineteenth century with a tightly-constructed long poem which is clearly influenced by the revolutionary mood of the 196os. But following Christensen's own references in her essays, I would like to use my preceding elaborations to illuminate the way in which the close connection between det and Die Lebrlinge zu Sais could further be examined.

Certainly, Novalis's reflections on the epistemological relevance of an experimental poetic thinking play a central role in Christensen's work. ${ }^{23}$ Her poetological reflections centre on the critique of a simple representational thinking where language is seen in opposition to nature. Like the disciples in Die Lebrlinge zu Sais, Christensen works with a very ambitious concept of experimental poetic praxis by which she tries to re-establish the primordial correspondences between language and nature. At the same time, language is constantly defined as a natural phenomenon in her writings. ${ }^{24}$ The correlating interest in the nature of language goes hand-in-hand with an interest in the languages of nature. In other words, Christensen tries to invent a complex, dynamic and self-emerging semiotic system - a Wunderschrift - that mirrors the network of equivalences established by the language of nature. Like Die Lebrlinge zu Sais, det is characterized by reflections on 'the morbid disposition of modern men' - a disposition characterized by insane 'divisions, dismemberments' and 'splittings' (quotes from Die Lebrlinge zu Sais, see above).

The cosmogony outlined in 'Prologos' (the first section of det) may serve as an illustration. 'Prologos' describes the decline of a vivid dynamic process that stiffens in fixed forms and finally freezes into the architectonic segmentation of urban life. However, the story of this progressive decline is subverted by the formal organisation of text that rests on ongoing dynamic interactions between typography and sound, visual and auditory elements, linguistic and mathematical structures. ${ }^{25}$

The fundamental dynamic structure of the 'Prologos' offers the basis for an immense number of metaphors which produce astonishing similarities and correspondences in 'Logos' (the main part of det). The poem 'Scene integriteter 5' [Stage integrities 5] showcases the attempt to create an experimental Wunderschrift. In this poem, Christensen uses a catalogue of composite words to establish correlations and blendings between natural, architectonic and bodily concepts as well as between the interior and the external world:

vandtrapper stenhimle vindhuse

luftkældre regnhjerter sandkroppe

klippemund flodmave iskøn

snelunger kulhjerner skyfingre

saltnerver jordøjne hjertesorg 
[watersteps stoneskies windhouses / aircellars rainhearts sandbodies / cliffmouths riverstomachs icesexes / snowlungs coalbrains cloudfingers / saltnerves eartheyes heartache ${ }^{26}$

As the general similarities between the philosophical dimensions of Christensen's poetry and Novalis's thinking are sufficiently documented in Haugland's and Svare's doctoral work, it is not necessary to dwell further on this aspect here. My point is that Haugland's attempt to differentiate between, on the one hand, the holistic philosophy of nature in romanticism, and, on the other hand, the more complex models of whole-part-relationships in contemporary science, should be reformulated in the light of the advanced semiotic reflections in Die Lebrlinge zu Sais. Novalis's text does not pay homage to a simple holistic thinking. On the contrary, its tropological observations could be used for critical reflections on the simple schemes and models of a holistic (mythical) world-view.

In essence, it could just as well be argued that Christensen's specific form of Naturphilosophie has more in common with Novalis's romantic concept of an experimentally and rhetorically inspired poetics of nature than with the trends in recent philosophy of nature to which Haugland refers. The close relation between Christensen's and Novalis's writing rhetorical strategies can be illustrated by their attempt to coalesce the constitution of a network of metaphorical correlations with an ongoing critique of metaphor. The criticism of the serious men in Die Lebrlinge $z u$ Sais (the men who accuse the disciples of 'savage nescience') ${ }^{27}$ finds its counterpart in Christensen's overt critique of her own (and of Novalis's) metaphors:

[O]rdene er ikke ét

med den verden de beskriver.

Ord har ikke vinger.

Og de hverken har eller får blomster.

[[T] he words are not one / with the world they describe. /

Words do not have wings / And they neither flower nor will. $]^{28}$

The renewal of an analogical thinking and the attempts to poeticize science are thus explicitly criticized in both texts. Both Die Lehrlinge zu Sais and det are characterized by a perpetual oscillation between naive enthusiasm and cool irony. ${ }^{29}$ Christensen amplifies this oscillating effect by confronting Novalis's complex reflections on a Wunderschrift with the far more prosaic writing-theories of phenomenology and structuralism..$^{30}$

As mentioned above, Die Lehrlinge zu Sais is structurally sophisticated. The different chapters and subchapters of the novel follow a similar scheme of triadic patterns. This means that the interest in structural equivalences thematised in the discourse of the disciples is reflected on a formal level. One could say that the text is shaped as an organic whole. However, as Jury Striedter has shown, this organizing principle is subverted by intentional contradictions and incon- 
sistencies. ${ }^{31}$ det is characterized by a similar contradiction. Despite the apparent correspondences between the individual parts of the poem (the three chapters 'SCENEN', 'HANDLINGEN' and 'TEKSTEN' of 'LOGOS' follow the same principle of eight subchapters each of which contain eight poems), the text cannot be described as a closed organic whole. Like Die Lehrlinge zu Sais, det must be described as a dynamic text informed by hidden inconsistencies and a principle of subtle displacement.

These general, structural similarities between Die Lebrlinge zu Sais and det recur in the rhetorical form of the single poems. Christensen's rhetoric is characterized by her frequent use of asymmetrical chiasmic structures: ${ }^{32}$

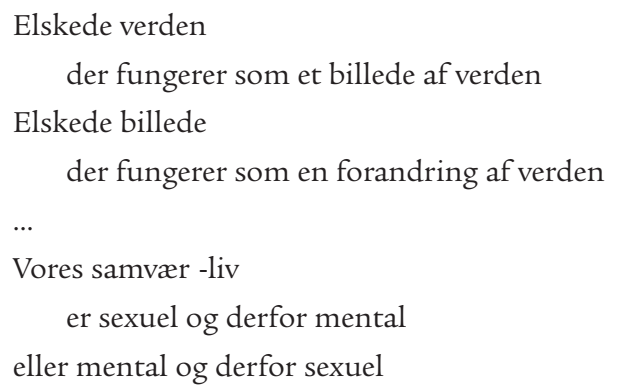

aktivitet elskede!

[Beloved world / that functions as an image of the world / Beloved image / that functions as a change in the world / ... / Our life together / is a sexual and therefore mental / or is a mental and therefore sexual / activity my love! $]^{33}$

The complex interconnection between 'the world' and 'the image', the 'mental' and 'the sexual' is reminiscent of Novalis's strategy of mutual representation and countersymbols.

Christensen, then, does not merely allude explicitly to Novalis's text. The close relations between det and Die Lehrlinge zu Sais show that she uses Novalis's fragment on a conceptual, structural, diegetic and rhetorical level. 


\section{Notes}

1 For a representative view, see Steffen Hejlskov-Larsen, Systemdigtningen. Modernismens tredje fase (Copenhagen: Munksgaard, 1971).

2 For a representative view on the relation between Christensen and Maurice Merleau-Ponty see Christine Seedorf, 'Utopi og dementi. Inger Christensens poetik i spændingsfeltet mellem skabelse og opløsning af betydning', Spring 18 (2002): 115-24; Klaus Müller-Wille, 'Sprachschleifen. Zu einer Theorie der Präposition in Inger Christensens det', in Topologie. Falten, Knoten, Netze, Stülpungen in Kunst und Theorie, ed. Ralph Ubl and Wolfram Pichler (Wien: Turia und Kant, 2009), 427-55. For a representative view on the relation between det and Dante's Divina Commedia see Bernhard Glienke, 'Themen in Systemen', Skandinavistik 5 (1975): 97-112.

3 See Anne Gry Haugland, Naturen $i$ änden. Naturfilosofien i Inger Christensens forfatterskab (Copenhagen: Institut for Nordiske Studier og Sprogvidenskab, 2012); Silje Ingeborg Harr Svare, Det umuliges kunst. Tidligromantisk aktualisering i Inger Christensens lyrikk (Oslo: Institut for lingvistiske og nordiske studier, 2014).

4 See Herbert Uerlings, Friedrich von Hardenberg, genannt Novalis. Werk und Forschung (Stuttgart: Metzler, 1991), 354.

5 Herbert Uerlings offers a good and detailed but somewhat outdated research survey on Die Lehrlinge zu Sais in his handbook; see Uerlings, Friedrich von Hardenberg, 353-82. The research of the last 20 years has been dominated by discourse-analytical studies on Novalis's relation to contemporary sciences. For a representative view see Jürgen Daibler, Experimentalphysik des Geistes. Novalis und das romantische Experiment (Göttingen: Vandenhoeck und Ruprecht, 2001), 169-212; Maximilian Bergengruen, 'Signatur, Hieroglyphe, Wechselrepräsentation. Zur Metaphysik der Schrift in Novalis' Lebrlingen', Athenäum. Jabrbuch der Friedrich-Schlegel-Gesellschaft 14 (2004): 43-67; Angelika Jacobs, Stimmungskunst von Novalis bis Hofmannsthal (Hamburg: Igel, 2013), 127-65.

6 Jury Striedter, 'Die Komposition der Lehrlinge zu Sais', in Novalis. Beiträge zu Werk und Persönlichkeit Friedrich von Hardenbergs, ed. Gerhard Schulz (Darmstadt: Wissenschaftliche Buchgesellschaft, 1970), 259-82, here 264.

7 Novalis, Die Lehrlinge zu Sais, here quoted from Inger Christensen, det (Copenhagen: Gyldendal, 1969), 184. The English translation is quoted from Novalis, The Disciples at Sais and other Fragments, trans. F.V. M.T. and U.C.B. (London: Methuen \& Co., 1903), here 110.

8 The German quotations follow Novalis, Die Lebrlinge zu Sais, in Novalis. Werke, Tagebücher und Briefe Friedrich Hardenbergs. Band 1. Das dichterische Werk, Tagebücher und Briefe, ed. Richard Samuel (Darmstadt: Wissenschaftliche Buchgesellschaft, 1999), 199-236, here 212-3. (Novalis, The Disciples at Sais, 110).

9 Novalis, Die Lehrlinge zu Sais, 201 (Novalis, The Disciples at Sais, 91).

10 See Inger Christensen, Hemmelighedstilstanden (Copenhagen: Gyldendal, 200o), 60-92.

11 A history of the conceptual metaphor of the book of nature is offered by Hans Blumenberg, Die Lesbarkeit der Welt (Frankfurt a.M.: Suhrkamp, 1989), 233-66 (on Novalis).

12 Daibler, Experimentalphysik des Geistes.

13 Novalis, Die Lebrlinge zu Sais, 202 (Novalis, The Disciples at Sais, 93).

14 Novalis, Die Lehrlinge zu Sais, 205. 
See Michel Foucault, Les mots et les choses. Une archéologie des sciences humaines (Paris: Gallimard, 1966). For a detailed analysis of the function of the early modern theories of signatures in the frame of Die Lehrlinge zu Sais, see Bergengruen, 'Signatur, Hieroglyphe, Wechselrepräsentation'.

16 Novalis, Die Lebrlinge zu Sais, 202 (Novalis, The Disciples at Sais, 93). For a detailed analysis on the topic of the senses in the novel see Reinhard Leusing, Die Stimme als Erkenntnisform - zu Novalis' Roman Die Lehrlinge zu Sais (Stuttgart: Metzler und Poeschel, 1993).

17 Novalis, Die Lebrlinge zu Sais, 220-1 (Novalis, The Disciples at Sais, 123).

18 Novalis, Die Lebrlinge zu Sais, 222 (Novalis, The Disciples at Sais, 126). For details on the importance of the Stimmungs-concept in Novalis's poetological reflexions, see Jacobs, Stimmungskunst, 127-65.

19 Novalis, Die Lebrlinge zu Sais, 220.

20 Novalis, Die Lebrlinge zu Sais, 202 (Novalis, The Disciples at Sais, 93-4).

21 The English translation is quoted from Novalis, Philosophical Writings, trans. and ed. Margaret Mahony Stoljar (New York: State University Press, 1997). 'Wechselrepräsentationslehre des Universums' is quoted from Novalis, Das Allgemeine Brouillon, in Novalis. Werke, Tagebücher und Briefe Friedrich Hardenbergs. Band 2. Das philosophisch-theoretische Werk, ed. Hans-Joachim Mähl (Darmstadt: Wissenschaftliche Buchgesellschaft, 1999), 471-718, here 499. The second translation is quoted by Novalis, Philosophical Writings, 132. 'Jedes Symbol kann durch sein Symbolisirtes wieder Symbolisiert werden - Gegensymbole' - see Novalis, Das Allgemeine Brouillon, 637. For details on Novalis's 'theory of the mutual representation of the universe', see Bergengruen, 'Signatur, Hieroglyphe, Wechselrepräsentation'.

22 Novalis, Die Lebrlinge zu Sais, 213 (Novalis, The Disciples at Sais, 110-1).

23 See the references to Novalis in the essays 'Den naive læser', 'Hemmelighedstilstanden', 'Det er ord alt sammen' og 'Tilfældighedens ordnende virkning' in Christensen, Hemmelighedstilstanden, $12-6,38-46,47-60$, and 6o-92.

24 On Christensen's paradoxical concept of a primordial beginning that must be created see Klaus Müller-Wille, 'Black box und Geheimniszustand - Anfang(en) als Wiederholung in der skandinavischen Systemdichtung', in Wiederholung. Literarische Verfahren und Funktionen, ed. Inka Mülder-Bach and Roger Lüdeke (Göttingen: Wallstein, 2006), 195-226.

25 Joachim Grage, 'Die Abwehr des Zufalls. Inger Christensen und die sprachbildende Kraft der Mathematik', in Zablen, Zeichen und Figuren. Mathematische Inspirationen in Kunst und Literatur, ed. Andrea Albrecht, Gesa von Essen, and Werner Frick (Berlin: de Gruyter, 2011), 510-28.

26 The present English Translation is quoted from Inger Christensen, it, trans. Susanna Nied (New York: New Directions, 2006), 81.

27 Novalis, Die Lebrlinge zu Sais, 213 (see the full quotation at the end of part 2 of this article).

28 Christensen, det, 53 (Christensen, it, 49).

29 See Jacobs, Stimmungskunst, 147-58.

30 On Christensen's attempt to combine phenomenological inspirations with structuralist models see Klaus Müller-Wille, 'Sprachschleifen'.

31 See Striedter, 'Die Komposition der Lebrlinge zu Sais'.

32 For details on Christensen's corresponding rhetorical practices see Niels Lyngsø, 'Mimesis, mimicry, mise-en-abîme', Kritik 125-6 (1997): 90-9.

33 Christensen, det, 78 (Christensen, it, 75). 